\title{
MODEL KAPABILITAS “CUSTOMER RELATIONSHIP MARKETING: PADA INDUSTRI TEPUNG TAPIOKA DI KABUPATEN PATI
}

\author{
Khoerul Umam \\ Universitas Islam Sultan Agung Semarang \\ Khoirulumam373@gmail.com
}

\begin{abstract}
This study aims to identify and analyze the influence of market information and human capital on the performance capabilities of CRM marketing company with variable inervening on tapioca starch industry in Pati regency with a sample size of 66 people. The sampling technique used in this research is purposive sampling. Analysis tools is the path analysis and the test results show that the human capital market information and found to have a positive and significant impact on CRM capabilities. Market information shown to have positive and significant impact on the performance of marketing, then the owner / entrepreneur will respond well to the changes that occur in the company, so as to improve the performance of the company's marketing. Human capital has a positive and significant impact on the performance marketing, means that increasing human capital, the company can exploit and develop the knowledge, competencies and skills of its employees efficiently, so that will have an impact on increasing the company's marketing performance. CRM capabilities have a significant positive effect on marketing performance. CRM capabilities are not able to become an intervening variable between market and human capital information with marketing performance. Thus the market information and human capital affects only the performance of the company's marketing but not through CRM capabilities.
\end{abstract}

Keywords: Market Information, Human Capital, CRM Capabilities and Marketing Performance.

\section{PENDAHULUAN}

Perkembangan perekonomian yang semakin kompetitif di lingkungan bisnis, menuntut perusahaan mempunyai kemampuan untuk beradaptasi agar tetap bertahan. Keberhasilan suatu organisasi dalam mencapai tujuannya juga tergantung faktor sumber daya manusia, dimana dibutuhkan suatu interaksi yang didesain untuk menghubungkan tugas-tugas, baik perseorangan maupun kelompok dalam rangka mencapai tujuan organisasi (Robbins, 2011).Dalam kegiatan usaha, bagian pemasaran memegang peranan sebagai media untuk melancarkan pelaksanaan kegiatan usaha tersebut.
Peranan tenagapemasaran yang handal dan profesional sangat diperlukan karena tenaga pemasaran merupakan ujung tombak perusahaan. Pemilik/ pengusahadituntut untuk memiliki strategi pemasaran yang berbasis pada upaya menciptakan hubungan antara pihak perusahaan dengan pelanggan lebih dikenal dengan istilah Customer Relationship Management (CRM). Customer Relationship Management (CRM) merupakan suatu strategi perusahaan yang digunakan untuk memanjakan pelanggan agar tidak berpaling kepada pesaing (Gaffar, 2007). Perusahaan yang secaraefektif mengimplementasikan CRM, sebagai strategi bisnis, berpeluang 
untukmenjadi pemimpin pasar (market leader).Menurut Sin et al. (2005) menyebutkan bahwa CRM merupakan strategi yang diperlukanperusahaan untuk mengoptimalkan keuntungan dalam meningkatkan kinerjanya.

Kinerja adalah hasil kerja secara kualitas dan kuantitas yang dicapai oleh individu dalam melaksannakan tugasnya sesuai dengan tanggung jawab yang diberikan kepadanya (Mangkunegara, 2012).

Banyak faktor yang dapat membuat perusahaan itu lebih kokoh di mata pasar yang bukan saja berasal dari aset fisik (tangible) yang dimiliki, namun juga dari aset tidak berwujud (intangible). Aset yang berwujud seperti kemampuan intelektual sebagai human capital, sedangkan aset yang tak berwujud tersebut seperti informasi pasar dapat meningkatkan kinerja perusahaan dan kekuatan perusahaan untuk bersaing (Margaretha dan Rakhman 2006). Perusahaan dalam kegiatan pemasarannya harus berusaha belajar untuk menyesuaikan diri dengan kondisi pasar, dimana perusahaan berada dan berusaha untuk mengembangkan kemampuan perusahaan dalam memproses informasi yang diperoleh perusahaan sehubungan dengan kondisi pasar (Ma'un, 2012). Human capital adalah pengetahuan yang dimiliki oleh karyawan melalui proses pendidikan dan pelatihan (Azua dan Azua., 1998 dalamsangkala., 2006). Banyak para pemimpin perusahaan kurang menyadari bahwa keuntungan yang diperoleh perusahaan sebenarnya berasal dari human capital.

Kabupaten Pati merupakan salah satu daerah yang sebagian besar penduduknya mempunyai usaha tepung tapioka. Hal itu dapat dilihat dengan banyaknya desa-desa penghasil tepung seperti Desa Ngemplak, Sidomukti dan Mojosemi. Banyaknya UMKM yang bermunculan menambah semakin kompetitifnya persaingan usaha tersebut. Dampak dengan tingginya persaingan juga mempengaruhi banyaknya UMKM yang gulung tikar. UMKM yang mampu bertahan adalah pengusaha yang mampu bekerja keras dengan memanfaatkan informasi pasar dengan baik.

Penurunan penjualan memberikan indikasi bahwa kinerja pemasaran selaku ujung tombak perusahaan memiliki kecenderungan kurang optimal. Menurunnya kinerja pemasaran tersebut disebabkan karena beberapa hal, diantaranya bahwa para pemilik atau tenaga pemasaran kurang efektif dalam survey pasar sehingga memiliki kecenderungan kurang informatif dalam mengetahui kondisi pasar. Fenomena lainnya juga menunjukkan bahwa kualitas sumber daya manusia kurang mendapat perhatian dalam mendorong daya saing perusahaan. namun sayang sekali di banyak perusahaan, sumber daya manusia masih jarang mendapat perhatian utama. Hal tersebut karena hanya human capital (SDM) yang dapat menciptakan pengetahuan dan sekaligus dapat meningkatkan kinerja yang dihasilkan.

Penelitian tentang kinerja perusahaan pernah dilakukan oleh beberapa peneliti, seperti yang dilakukan Wright dan Ashill (1998) menunjukkan bahwa informasi pasar berpengaruh positif terhadap kinerja perusahaan, sedangkan Weiber dan Kollmann (1998) bahwa informasi pasar justru tidak berpengaruh terhadap kinerja perusahaan. Sedangkan Christa (2013) menunjukkan bahwa human capital mempunyai pengaruh positif terhadap kinerja organisasi. Sedangkan pada penelitian Juwita (2007) terjadi sebaliknya bahwa human capital tidak berpengaruh terhadap kinerja bisnis.

Berdasarkan hasil penelitian tersebut menunjukkan kontradiksi antara peneliti satu dengan lainnya. Untuk itu dalam penelitian ini akan menguji kembali dengan mengacu pada penelitian terdahulu yang hasilnya masih inkonsisten. 


\section{KAJIAN PUSTAKA}

\section{Kapabilitas Customer Relationship Marketing}

Customer Relationship Management (CRM) merupakan strategi inti dalam bisnis yang mengintegrasikan proses-proses dan fungsi-fungsi internal dengan semua jaringan eksternal untuk menciptakan serta mewujudkan nilai bagi para konsumen sasaran secara profitabel" (Buttle, (2007). Sedangkan Wang \& Feng (2012) mendefinisikan CRM sebagai proses lintas fungsional yang dilakukan organisasi yang berfokus dalam membangun, mempertahankan dan meningkatkan hubungan jangka panajang dalam rangka menarik pelanggan. Berdasarkan pengertian tersebut di atas dapat disimpulkan bahwa Relationship Marketing dan CRM memiliki definisi yang hampir sama, yaitu berpusat pada hubungan penjual dengan pelanggan, hubungan tersebut sifatnya jangka panjang dan kedua pihak mendapat manfaat di dalam hubungan yang dibuat (simbiosis mutualisme). Pada intinya, CRM mempunyai konsep dasar untuk menarik pelanggan baru, mengenal mereka dengan baik, memberikan mereka pelayanan yang luar biasa, dan mengantisipasi keinginan dan kebutuhan mereka serta mempertahankan pelanggan lama untuk tetap merasa dihargai dan dibutuhkan oleh perusahaan. Untuk mengimplementasikan sebuah strategi CRM, diperlukan paling tidak 3 (tiga) faktor kunci yaitu (1) orang-orang yang profesional (kualifikasi memadai),

(2) proses yang didesain dengan baik dan

(3) teknologi yang memadai (leading-edge technology).Menurut Wang \& Feng (2012) bahwa kapabilitas CRM dapat diukur antara lain dengan :

\section{Customer Interaction Management Capability}

Kemampuan manajemen untuk berinteraksi dengan pelanggan mengacu pada keterampilan bahwa perusahaan menggunakan untuk mengidentifikasi, memperoleh dan mempertahankan pelanggan agar menguntungkan

Customer Relationship Ugrading Capability

Customer Relationship Ugrading Capability kemampuan yang mengacu pada keterampilan perusahaan dalam menggunakan teknologi untuk memasarkan produk kepada pelanggan yang ada berdasarkan analisis data pelanggan ilmiah

\section{Customer Win-Back Capability}

Customer Win-Back Capability adalah kemampuan perusahaan dengan memanfaatkan teknologi untuk membangun hubungan kembali yang hilang atau tidak aktif tapi menguntungkan pelanggan sejak hilangnya para pelanggan akan memiliki dampak negatif yang sangat besar pada perusahaan kinerja dalam jangka panjang.

CRM adalah strategi yang berfokus pada penciptaan kepuasan pelanggan dan hubungan jangka panjang dengan mengintegrasikan beberapa area fungsional perusahaan untuk meraih keunggulan bersaing (Payne \& Frow, 2005; Chadhiq, 2007; Chang, 2007; Nguyen, Sherif, \& Newby, 2007). Sebenarnya alasan paling mendasar yang mendorong perusahaan untuk membina hubungan dengan pelanggan sesungguhnya sangat klasik yaitu motif ekonomi (Chadhiq, 2007). Seperti yang diketahui, pemasukan terbesar dari proses bisnis perusahaan berasal dari pelanggan, baik secara langsung maupun tidak langsung, oleh sebab itu maka perusahaan perlu untuk mengidentifikasi, memuaskan dan mempertahankan pelanggan yang paling menguntungkan (Buttle dalam Chadhiq, 2007)

\section{Informasi Pasar}

Pengumpulan informasi pasar dan penyebaran informasi pasar merupakan mekanisme yang erat kaitannya dengan organizational learning (Maun, 2012). Sinkula, Baker dan Noordewier (1997) memberikan pengertian informasi pasar 
sebagai proses pengumpulan, proses penyebaran, proses interpretasi organisasi dan proses memori organisasi dalam mempengaruhi kinerja pasar. Informasi pasar merupakan sekumpulan data/fakta yang diperoleh dari proses pengamatan pelanggan dan pesaing.

Slater dan Narver (1995) berpendapat bahwa harus ada kesepakatan bersama di perusahaan dalam mengartikan atau menginterpretasikan informasi-informasi yang akan dikumpulkan perusahaan dan implikasi-implikasi dari penggunaan informasi tersebut dalam bisnis perusahaan. Dess dan Origer (1987) menyatakan bahwa perusahaan yang berada dalam lingkungan pasar yang dinamis dan kompleks harus menekankan pula kesepakatan dalam menginterpretasikan informasi. Pengukuran yang sahih untuk informasi pasar menurut Tjiiptono dan Chandra (2007) terdiri 4 orientasi, antara lain sebagai berikut :

Orientasi pelanggan mencakup semua aktivitas yang berkontribusi pada pemahaman dan perusahaan terhadap kebutuhan dan preferensi para pelanggan sasarannya dan pada kemampuan perusahaan untuk merancang produk dan jasa yang bisa memuaskan kebutuhan dan preferensi tersebut. Orientasi pelanggan (customer orientation) diartikan sebagai pemahaman yang memadai terhadap pembeli sasaran, sehingga superior value dapat diberikan secara terus menerus (Prakoso dan Ghozali, 2005).

Orientasi pesaing mencerminkan pemahaman terhadap kekuatan dan kelemahan jangka pendek dan kapabilitas dan strategi jangka panjang para pesaing utama saat ini dan pesaing potensial utama perusahaan, serta kemampuan merespons aktivitas dan strategi pesaing. Orentasi pesaing mempunyai keterkaitan yang kuat dengan orientasi pelanggan dalam hal pengumpulan informasi (informasigathering) dan mencakup analisis menyeluruh terhadap kapabilitas memuaskan pembeli sasaran yang lama.
Koordinasi antar fungsi mengacu pada tingkat koordinasi antar fungsi atau departemen berbeda dalam sebuah perusahaan dan tingkat penyebarluasan informasi antar departemen. Koordinasi antar fungsi intra perusahaan merefleksikan pendayagunaan secara terkoordinasi dari seluruh sumber daya yang ada dalam perusahaan dalam rangka menciptakan superior value bagi pembeli sasaran (Naver dan Slater, 1995).

Orientasi laba meliputi pemantauan dan pemahaman terhadap profitabilitas masingmasing kategori produk individual dan produk pemasok. Dalam hal ini orientasi laba tersebut terdiri dari kemampuan perusahaan untuk menentukan profitabilitas kategori produk individual.

Keefektifan dari proses pengolahan informasi pasar sangat bergantung pada:

Kemampuan perusahaan dalam menginterpretasikan informasi seperti: gambaran tentang kondisi nyata di pasar, asumsi tentang kondisi pasar, hubunganhubungan kunci dalam tindakan perusahaan.

Hasil yang diperoleh perusahaan, dimana hasil tersebut akurat dan disebarkan di seluruh bagian perusahaan (Senge, 1990).

\section{Human Capital}

Human capita/mencakup seperangkat kemampuan, sifat dan sikap dari karyawan suatu perusahaan (Choong, 2008). Lebih lanjut Sveiby (1998) menjelaskan bahwa human capital merupakan kompetensi individu sebagai kapasitas karyawan untuk bertindak didalam berbagai situasi. Dilengkapi pandangan lain yang menyatakan bahwa, human capital adalah pengetahuan yang dimiliki oleh karyawan melalui proses pendidikan dan pelatihan (Azua dan Azua., 1998).

Human capital merupakan darah kehidupan bagi modal intelektual, sebagai generator dari seluruh nilai yang lahir dalam potensi inovasi dari perusahaan sekaligus kekuatan dibalik inovasi (Christa, 2013). Human capital merupakan sumber 
innovation dan improvement, karena di dalamnya terdapat pengetahuan, ketrampilan dan kompetensi yang dimiliki oleh karyawan perusahaan.

Human capital penting karena merupakan sumber inovasi dan pembaharuan strategi yang dapat diperoleh dari brainstorming melalui riset laboratorium, impian manajemen, process reengineering, dan perbaikan atau pengembangan ketrampilan pekerja. Selain itu, human capital memberikan nilai tambah dalam perusahaan setiap hari, melalui motivasi, komitmen, kompetensi serta efektivitas kerja tim. Nilai tambah yang dapat dikontribusikan oleh pekerja berupa: pengembangan kompetensi yang dimiliki oleh perusahaan, pemindahan pengetahuan dari pekerja ke perusahaan serta perubahan budaya manajemen (Mayo 2000).

Pembentukan nilai tambah yang dikontribusikan oleh human capital dalam menjalankan tugas dan pekerjaannya akan memberikan sustainable revenue di masa akan datang bagi suatu organisasi (Malhotra 2003 dan Bontis 2002).

Human Capital penting karena merupakan sumberdaya inovasi dan strategi yang terbarukan, meskipun berasal dari brainstorming dalam penelitian laboratorium, lamunan di kantor, membuka kembali data yang lama, perancangan kembali proses baru, peningkatan kemampuan personal (Bontis et al., 2000). Untuk mengetahui instrumen human capital dapat dijelaskan dengan indikator antara lain melalui adanya ide-ide baru, kerja sama dalam tim, peduli terhadap konsumen, memberikan seluruh upaya dan kepercayaan (Bontis, 1997)

\section{Kinerja Pemasaran}

Menurut Mangkunegoro (2011) kinerja didefinisikan sebagai hasil kerja secara kualitas dan kuantitas yang dicapai oleh seseorang dalam melaksanakan tugasnya sesuai dengan tanggung jawab yang diberikan kepadanya. Pendapat lain disampaikan Simamora (2009) bahwa kinerja adalah tingkat pada tahap mana karyawan mencapai persyaratanpersyaratan pekerjaan. Kinerja perusahaan adalah kemampuan organisasi untuk mencapai tujuannya dengan menggunakan sumber daya secara efisien dan efektif (Daft, 2000). Kinerja perusahaan menggambarkan sejauh mana organisasi ini mampu memenuhi kebutuhan para pemangku kepentingan dan kebutuhannya sendiri untuk bertahan hidup (Griffin, 2003).

Kinerja didefinisikan sebagai ukuran pencapaian tujuan organisasi. Menurut Daft (2009) bahwa kinerja bisnis dapat dikur dengan pangsa pasar, penjualan produk dan layanan baru, tingkat pengembalian investasi, selain evaluasi faktor internal seperti proses tambahan dan pengurangan waktu respon terhadap perubahan di pasar. Menurut Rappet et.al. (2008) indikator kinerja bisnis diukur melalui pangsa pasar, persentase baru penjualan produk terhadap total penjualan dan laba atas investasi (ROI), sedangkan Goldet al. (2001) mengukur kinerja melalui orangorang dari organisasi yang bersangkutan kompetisi, kelincahan proses internal dan waktu respon terhadap perubahan pasar. Wang \& Feng (2012) juga menjelaskan bahwa kinerja bisnis dapat diukur antara lain dengan kinerja secara keseluruhan (overall performance), pertumbuhan volume penjualan (market share), pertumbuhan penjualan (sales growth), keuntungan (profitability) dan kepuasan pelanggan (customer satisfaction).

\section{Kerangka Pemikiran Teoritis}

Kerangka teori merupakan penuntun bagi peneliti dalam melaksanakan penelitian untuk memecahkan masalah. Penyusunan kerangka teori termasuk bagian yang sangat penting dan merupakan petunjuk tentang keterikatan pengaruh antar variabel. Untuk mengetahui keterikatan pengaruh antar variabel, dapat dijelaskan dalam kerangka pemikiran berikut ini: 


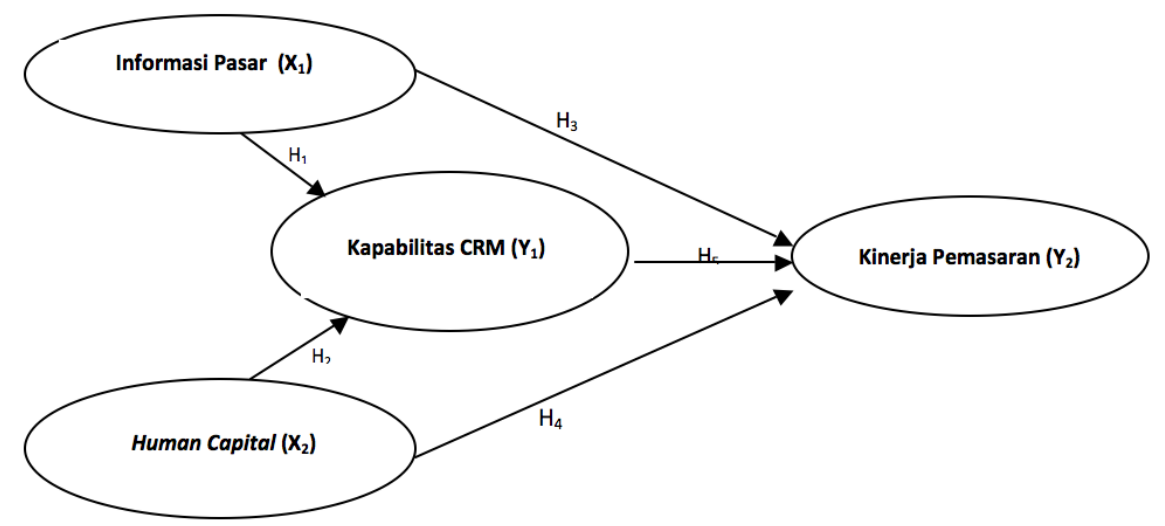

Gambar 2.1.

Kerangka Pemikiran Teoritis

\section{Pengembangan Hipotesis \\ Pengaruh Informasi Pasar terhadap Kapabilitas CRM}

Perusahaan dalam kegiatan pemasarannya berusaha belajar untuk menyesuaikan diri dengan kondisi pasar dimana perusahaan berada dan berusaha untuk mengembangkan kemampuan perusahaan dalam memproses informasi yang diperoleh perusahaan sehubungan dengan kondisi pasar. Pengumpulan informasi pasar adalahproses dimana informasi-informasi yangdiperlukan perusahaan dikumpulkan (Argyrisdan Schon 2003). Selanjutnya, Slaterdan Narver (1995) menyatakanbahwa informasi pasar dapat diperoleh daripengalaman langsung perusahaan,pengalaman perusahaan lain atau memoriperusahaan (memori organisasi).

Semakin tinggi informasi pasar yang dimiliki SDM dengan memanfaatkan teknologi informasi, maka kemampuan untuk memahami CRM akan semakin baik untuk mengantisipasi perilaku negatif pada saat berinteraksi langsung denganpelanggan. Menurut Ferdinand (2000) mengatakan bahwa informasi terhadap sumber dayaperusahaan sangat diperlukan, salah satunya adalah sumber daya manusia, sehingga harus dikeloladengan upayaupaya yang sistematis untuk menghasilkan superior value bagipelanggan.

Dalam perspektif manajemen pemasaran strategik permasalahan tersebutdapat diatasi dengan penerapan customer relationship management(CRM) karenastrategi ini berkorelasi dengan penciptaan informasi pasar, penciptaan keunggulanbersaing, dan hubungan jangka panjang yangsaling menguntungkan antara perusahaaan dengan pelanggan. Penelitian Sarwana dan Indra (2011) terbukti bahwa informasi pasar berpengaruh positif terhadap penerapan CRM.

$\mathrm{H}_{1} \quad$ Informasi pasar berpengaruh positif dan signifikan terhadap kapabilitas CRM

\section{Pengaruh Human Capital terhadap Kapabilitas CRM}

Human capital merupakan sumber innovation dan improvement, karena di dalamnya terdapat pengetahuan, ketrampilan dan kompetensi yang dimiliki oleh karyawan perusahaan. Dengan memiliki karyawan yang berkeahlian dan berketerampilan, maka karyawan harus berusaha untuk menjaga hubungan baik dengan pelanggan. Menurut Azua dan Azua (1998) dalam sangkala (2006) bahwa peran human capital sangat penting dalam penciptaan kekayaan intelektual (intellectual assets) yang sangat strategis, karena hanya human capital (SDM) yang dapat 
menciptakan pengetahuan dan sekaligus dapat meningkatkan kinerja yang dihasilkan.

Dalam hal ini keahlian dan ketrampilan tersebut dilakukan untuk menjaga pelanggan (supaya tidak lari ke pesaing) dengan mengumpulkan segala bentuk interaksi pelanggan baik itu lewat telepon, email, masukan di situs atau hasil pembicaraan dengan staf sales dan marketing. Semakin tinggi keahlian dan ketrampilan karyawan, maka memungkinkan untuk menerapkan strategi bisnis menyeluruh dari suatu perusahaan yang memungkinkan perusahaan tersebut secara efektif bisa mengelola hubungan dengan para pelanggan. Penelitian ini mendukung Christa (2013) menunjukkan bahwa human capital mempunyai pengaruh positif terhadap kapabilitas CRM

$\mathrm{H}_{2} \quad$ Human capital berpengaruh positif dan signifikan terhadap kapabilitas CRM

\section{Pengaruh Informasi Pasar terhadap Kinerja Pemasaran}

Perusahaan dalam kegiatan pemasarannya berusaha belajar untuk menyesuaikan diri dengan kondisi pasar dimana perusahaan berada dan berusaha untuk mengembangkan kemampuan perusahaan dalam memproses informasi yang diperoleh perusahaan sehubungan dengan kondisi pasar. Semakin tinggi informasi pasar yang diterima, maka akan semakin meningkatkan persaingan pasar, sehingga perusahaan akan meningkatkan jarak produk dan mengurangi siklus hidup produk, memperkenalkan saluran distribusi baru yang mempengaruhi rantai suplai konsumen, menghadapi sensitivitas pasar dan menargetkan produk serta jasa kepada segmen-segmen pelanggan (Rolfe, 1922).

$$
\text { Menurut DeGeus }
$$

menyebutkan bahwa dalam rangka mempertahankan keunggulan bersaing, perusahaan memerlukan informas pasar yang baik dalam menyesuaikan diri dengan cepat terhadap lingkungan pasar dalam meningkatkan kinerja yang dihasilkan. Pada penelitian Wright dan Ashill (1998) menunjukkan bahwa informasi pasar berpengaruh positif terhadap kinerja perusahaan.

$\mathrm{H}_{3} \quad$ Informasi pasar berpengaruh signifikan terhadap kinerja pemasaran melalui kapabilitas CRM

\section{Pengaruh Human Capital terhadap Kinerja Pemasaran}

Human capital adalah unsur yang sangat penting dari modal intelektual, karena dapat menciptakan daya saing bagi organisasi/ perusahaan. Hubungan human capital dengan kinerja telah dibuktikan secara empiris oleh beberapa peneliti dalam berbagai pendekatan di beberapa negara. human capital diyakini dapat berperan penting dalam peningkatan nilai organisasi maupun kinerja perusahaan (Ramanda dan Mochtar, 2014). Berdasarkan hasil penelitian yang dilakukan oleh Saeed, dkk (2013) telah membuktikan bahwa human capital mempunyai pengaruh positif terhadap kinerja organisasi.

Penelitian yang telah dilakukan oleh Mehralian, et.al (2012) menjelaskan bahwa terdapat hubungan timbal balik diantara human capital terhadap kinerja organisasi. Dan jika semua komponen di kombinasikan, hal ini juga membuktikan bahwa human capital merupakan komponen utama yang mempengaruhi kinerja. Pada penelitian Christa (2013) menunjukkan bahwa human capital mempunyai pengaruh positif terhadap kinerja organisasi.

$\mathrm{H}_{4} \quad$ Human capital berpengaruh positif dan signifikan terhadap kinerja pemasaran

\section{Pengaruh Kapabilitas CRM terhadap Kinerja Pemasaran}

Sin et al. (2005) menjelaskan bahwa kapabilitas CRM merupakan strategi yang diperlukan perusahaan untuk mengoptimalkan keuntungan dalam meningkatkan kinerja yang dihasilkan. 
Perusahaan yang secara efektif mengimplementasikan CRM, sebagai strategi bisnis, berpeluang untuk menjadi pemimpin pasar (market leader).

Strategi bisnis, secara teoritis, akan menciptakan keunggulan bersaing dalam pasar tetapi kesalahan dalam pengimplementasinnya tidak akan menghasilkan keuntungan apapun. Hal tersebut mengundang minat pembahasan berkenaan implementasi strategi (Sin et al., 2005). Hasil penelitian ini didukung oleh penelitian Chang (2007), Fazlzadeh, et.al (2011), Nguyen, et.al (2007), Coltman, et.al (2011) serta Wang dan Feng (2012) yang menyatakan bahwa kapabilitas CRM berpengaruh positif dan signifikan terhadap kinerja bisnis.

$\mathrm{H}_{5} \quad$ Kapabilitas CRM berpengaruh signifikan terhadap kinerja pemasaran

\section{Metode Penelitian \\ Populasi dan Sampel}

Populasi menurut Sugiyono (2011), adalah wilayah generalisasi yang terdiri dari subyek atau subyek yang mempunyai kualitas dan karakteristik tertentu yang ditetapkan oleh peneliti untuk dipelajari dan kemudian ditarik kesimpulannya. Populasinya adalah pemilik/pengusaha pada industri tepung tapioka di Kabupaten Pati sebesar 162 orang.

Sampel adalah sebagian dari jumlah populasi yang diambil untuk diteliti dan karakteristiknya hendak diduga. Untuk memberikan hasil yang akurat, maka jumlah sampel yang diambil dengan menggunakan rumus Slovin (Umar, 2008):

$$
\mathrm{n}=\frac{\mathrm{N}^{--}}{1+\mathrm{Ne}^{2}}
$$

\section{KETERANGAN :}

$\mathrm{n}=$ Jumlah sampel

$\mathrm{N}=$ Jumlah populasi

$\mathrm{Ne}^{2}=$ Persen kelonggaran ketidaktelitian, kesalahan pengambilan sampel yang masih dapat ditolerir (10\%).

Berdasarkan rumus diatas didapat hasil sebanyak 62 , maka sampel dalam penelitian ini adalah pemilik atau pengusaha pada industri tepung tapioka di Kabupaten Pati sebanyak 62 responden sebagai sampel minimalnya.

Teknik pengambilan sampel yang digunakan dalam penelitian ini adalah Purposive Sampling, yaitu teknik penentuan sampel berdasarkan pertimbangan tertentu (Sugiyono, 2011).

\section{HASIL DAN PEMBAHASAN Uji Validitas}

Validitas diukur dengan melihat KMO dan loading factor (component matriks). Bila KMO lebih dari 0,5 dan signifikansinya < 0,05 dan loading factor lebih dari 0,4 maka item yang bersangkutan adalah valid. ada pada Tabel 1.

Hasil uji validitas untuk nilai Kaiser Meiyer Olkin (KMO) pada ke empat variabel informasi pasar, human capital, kapabilitas CRM dan kinerja pemasaran telah melebihi dari nilai yang ditetapkan, sebesar 0,5 sehingga dapat diasumsikan bahwa data

Tabel 1

Uji Validitas KMO

\begin{tabular}{|c|c|c|c|c|}
\hline Variabel Penelitian & $\begin{array}{l}\text { Nilai } \\
\text { KMO }\end{array}$ & $\begin{array}{l}\text { Tingkat } \\
\text { Kesalahan }\end{array}$ & Keterangan & \\
\hline Informasi pasar & 0,752 & 0,5 & Memenuhi & kriteria \\
\hline Human capital & 0,827 & 0,5 & Memenuhi & kriteria \\
\hline Kapabilitas CRM & 0,880 & 0,5 & Memenuhi kri & \\
\hline Kinerja pemasaran & 0,845 & 0,5 & Memenuhi kri & \\
\hline
\end{tabular}


Indikator Variabel

\begin{tabular}{|c|c|c|c|c|c|}
\hline Variabel & Indikator & $\begin{array}{l}\text { Nilai } \\
\text { Communalities }\end{array}$ & $\begin{array}{l}\text { Nilai } \\
\text { Componen } \\
\text { Matrix }\end{array}$ & $\begin{array}{l}\text { Batas } \\
\text { valid }\end{array}$ & Ket. \\
\hline \multirow{6}{*}{ Informasi pasar } & \multirow{6}{*}{$\begin{array}{l}\text { Instrumen } 1 \\
\text { Instrumen } 2 \\
\text { Instrumen } 3 \\
\text { Instrumen } 4\end{array}$} & 0,750 & & & \\
\hline & & & 0,866 & 0,4 & Valid \\
\hline & & 0,847 & 0,920 & 0,4 & Valid \\
\hline & & 0683 & 0,826 & 0,4 & Valid \\
\hline & & 0,000 & 0,717 & 0,4 & Valid \\
\hline & & 0,515 & & & \\
\hline \multirow{5}{*}{ Human capital } & Instrumen 1 & 0,700 & 0,837 & 0,4 & Valid \\
\hline & Instrumen 2 & 0,668 & 0,817 & 0,4 & Valid \\
\hline & Instrumen 3 & 0,779 & 0,883 & 0,4 & Valid \\
\hline & Instrumen 4 & 0,761 & 0,872 & 0,4 & Valid \\
\hline & Instrumen 5 & 0,803 & 0,896 & 0,4 & Valid \\
\hline \multirow{9}{*}{ Kapabilitas CRM } & Instrumen 1 & 0,866 & 0,887 & 0,4 & Valid \\
\hline & Instrumen 2 & 0,698 & 0,825 & 0,4 & Valid \\
\hline & Instrumen 3 & 0,795 & 0,862 & 0,4 & Valid \\
\hline & Instrumen 4 & 0,772 & 0,875 & 0,4 & Valid \\
\hline & Instrumen 5 & 0,642 & 0,780 & 0,4 & Valid \\
\hline & Instrumen 6 & 0,732 & 0,723 & 0,4 & Valid \\
\hline & Instrumen 7 & 0,857 & 0,655 & 0,4 & Valid \\
\hline & Instrumen 8 & 0,744 & 0,798 & 0,4 & Valid \\
\hline & Instrume 9 & 0,825 & 0,860 & 0,4 & Valid \\
\hline \multirow{5}{*}{ Kinerja pemasaran } & Instrumen 1 & 0,747 & 0,864 & 0,4 & Valid \\
\hline & Instrumen 2 & 0,699 & 0,836 & 0,4 & Valid \\
\hline & Instrumen 3 & 0,769 & 0,877 & 0,4 & Valid \\
\hline & Instrumen 4 & 0,685 & 0,827 & 0,4 & Valid \\
\hline & Instrumen 5 & 0,523 & 0,723 & 0,4 & Valid \\
\hline
\end{tabular}

cukup dilakukan analisis faktor. Untuk dapat menggambarkan konsistensi internal, maka dapat dilihat dari nilai loading, ada pada tabel 2.

Tabel di atas menunjukkan pada masingmasing variabel yaitu informasi pasar, human capital, kapabilitas CRM dan kinerja pemasaran menunjukkan hasil yang valid. Terbukti dengan semua nilai loading yang terlihat dari nilai component matrix telah melebihi dari batas kelayakan sebesar 0,4, sehingga dengan demikian masing-masing indikator pada masing-masing variabel tersebut dapat dilakukan kepada langkah penghitungan selanjutnya.

\section{Uji Reliabilitas}

Adapun kriteria apabila dikatakan reliabel atau dapat dipercaya yaitu apabila nilai $r$ hitung > nilai standarisasi yang ditentukan sebesar 0,6 (Ghozali, 2011). Berikut hasil pengujian reliabilitas pada masing-masing variabel :

Dapat diketahui bahwa masing-masing

\section{Uji Reliabilitas Variabel}

\begin{tabular}{lrrrl}
\hline Variabel & $\begin{array}{l}\text { Nilai } \\
\text { Crobanch Alpha }\end{array}$ & $\begin{array}{l}\mathrm{N} \\
\text { Standarisasi }\end{array}$ & Keterangan \\
\hline Informasi pasar & 0,854 & & 0,6 & Reliabel \\
Human capital & 0,913 & & 0,6 & Reliabel \\
Kapabilitas CRM & 0,933 & & 0,6 & Reliabel \\
Kinerja pemasaran & 0,883 & & 0,6 & Reliabel \\
\hline
\end{tabular}


variabel, yaitu informasi pasar, human capital, kapabilitas CRMdan kinerja pemasaran diperoleh nilai cronbanch alpha telah melebihi dari batas yang ditentukan sebesar 0,6. Dengan demikian, hasil uji reliabilitas terhadap keseluruhan variabel adalah reliable atau dapat dipercaya.

\section{Pengujian Hipotesis \\ Pengaruh Informasi \\ PasarTerhadapKapabilitasCRM}

Hasil pengujian informasi pasar terhadap kapabilitas CRMdiperoleh nilai $\mathrm{t}$ hitung sebesar 4,178 dengan nilai signifikansi sebesar $0,000<0,05$, sedangkan pada taraf signifikansi 0,05 dan degres of freedom (df) sebesar 63 maka diperoleh nilai t tabel sebesar 1,998, sehingga nilai $\mathrm{t}$ hitung $=$ $4,178>$ nilai $t$ tabel $=1,998$. Penjelasan tersebut dapat diartikan bahwa informasi pasar mempunyai pengaruh positif dan signifikan terhadap kapabilitas CRM. Dengan hasil tersebut disimpulkan bahwa pengujian mampu menerima hipotesis kedua, sehingga dugaan informasi pasar terhadap kapabilitas CRMterbukti atau dapat diterima.

\section{Pengaruh Human Capitalterhadap Kapabilitas CRM}

Hasil pegujian human capital terhadap kapabilitas CRM diperoleh nilai $t$ hitung sebesar 2,740 dengan hasil signifikansi sebesar $0,008<0,05$. Dengan demikian nilai $\mathrm{t}$ hitung $=2,740>$ nilai $\mathrm{t}$ tabel $=1,998$. Dengan hasil tersebut pengujian mampu menerima hipotesis ketiga, dapat diartikan bahwa human capital mempunyai pengaruh positif dan signifikan terhadap kapabilitas CRM. Berdasarkan hasil pengujian dugaan adanya pengaruh positif antara human capital terhadap kapabilitas CRM dapat diterima.

a. Pengaruh Informasi Pasar terhadap Kinerja Pemasaran

Hasil pengujian informasi pasar terhadap kinerja pemasaran diperoleh nilai $t$ hitung sebesar 2,271 dengan hasil signifikansi sebesar $0,027<0,05$. Pada degree offreedom sebesar $62(n-k-1 ; 66-3-1)$, diperoleh nilai $t$ tabel sebesar 1,999 , sehingga nilai $t$ hitung $=2,271>$ nilai t tabel $=1,999$. Hal ini menunjukkan terdapat pengaruh positif dan signifikaninformasi pasar terhadap kinerja pemasaran. Berdasarkan hasil pengujian menunjukkan bahwa pengujian tersebut mampu menerima hipotesis keempat, sehingga dugaan informasi pasar terhadap kinerja pemasaran tersebut terbukti atau dapat diterima.

\section{Pengaruh Human CapitalterhadapKinerja Pemasaran}

Berdasarkan hasil output untuk pengaruh langsung antara human capital terhadap kinerja pemasaran, diperoleh nilai $t$ hitung sebesar 2,291 dengan nilai signifikansi sebesar 0,025 lebih kecil dari tingkat kesalahan sebesar 0,05 , sehingga nilai $\mathrm{t}$ hitung $=2,291>$ nilai $\mathrm{t}$ tabel $=1,999$. Dengan hasil tersebut, maka pengujian mampumenerima hipotesis kelima, artinya bahwa human capital mempunyai pengaruh positifdan signifikan terhadap kinerja pemasaran. Berdasarkan hasil pengujian dapat disimpulkan bahwa dugaan adanya pengaruh human capital terhadap kinerja pemasaranterbukti atau dapat diterima.

\section{Pengaruh Kapabilitas \\ CRMterhadapKinerja Pemasaran}

Hasil pengujian kapabilitas CRM terhadap kinerja pemasaran, diperoleh nilai $t$ hitung sebesar 6,265 dengan nilai signifikansi sebesar $0,000<0,05$, sehingga nilai t hitung $=6,265>$ nilai $t$ tabel $=1,999$. Penjelasan tersebut dapat diartikan bahwa kapabilitas CRM mempunyai pengaruh positifdan signifikan terhadap kinerja pemasaran. Dengan hasil tersebut dapat disimpulkan bahwa dugaan adanya pengaruh kapabilitas CRM terhadap kinerja pemasaran terbukti atau dapat diterima.

\section{Pengaruh Informasi Pasar terhadap Kinerja Pemasaran melalui Kapabilitas}




\section{CRM}

Untuk mengetahui apakah kapabilitas CRM mampu menjadi variabel intervening antara informasi pasar dengan kinerja pemasaran maka diperoleh nilai sobel test dengan test statisticnya sebesar 1,719128 dengan nilai standart erromya sebesar 0,15023 dan nilai $P$-valuenya sebesar 0,085 yang berarti nilai tersebut di atas batas yang ditentukan tingkat kesalahannya sebesar 0,05 . Penjelasan tersebut memberikan pengertian jika kapabilitas CRM tidak mampu menjadi variabel intervening antara informasi pasar dengan kinerja pemasaran. Dengan demikian informasi pasar hanya berpengaruh terhadap kinerja pemasaran tetapi tidak melalui kapabilitas CRM.

\section{Pengaruh Human Capital terhadap Kinerja Pemasaran melalui Kapabilitas CRM}

Hasil pengujian sobel test antara variabel human capital terhadap kinerja pemasaran melalui kapabilitas CRM, maka diperoleh nilai sobel test dengan test statistiknya sebesar 1,473 dengan nilai standart erromya sebesar 0,115 dan nilai $P$-valuenya sebesar 0,141 yang berarti nilai tersebut di atas batas yang ditentukan tingkat kesalahannya sebesar 0,05 . Penjelasan tersebut memberikan pengertian jika kapabilitas CRM tidak mampu menjadi variabel intervening antara human capital dengan kinerja pemasaran. Dengan demikian human capital hanya berpengaruh terhadap kinerja pemasaran tetapi tidak melalui kapabilitas CRM.

\section{Pembahasan}

\section{Pengaruh Informasi Pasar terhadap Kapabilitas CRM}

Informasi pasar terbukti mempunyai pengaruh positif dan signifikan terhadap kapabilitas CRM, dapat diartikan bahwa semakin tinggi informasi pasar yang diterima, maka pemilik/pengusaha tersebut akan merespon dengan baik terhadap perubahanperubahan yang terjadi pada perusahaan, sehingga mampu meningkatkan kapabilitas pengetahuan tentang keinginan pelanggan, dinamika pasar dan pesaing. Dalam perspektif manajemen pemasaran strategik permasalahan tersebut dapat diatasi dengan penerapan customer relationship management (CRM) karena strategi ini berkorelasi dengan penciptaan informasi pasar, penciptaan keunggulan bersaing, dan hubungan jangka panjang yang saling menguntungkan antara perusahaaan dengan pelanggan. Banyaknya permintaan pelanggan juga harus diimbangi dengan tingginya kemampuan pemilik/pengusaha dalam mengetahui tentang keinginan pelanggan, dinamika pasar dan banyaknya pesaing, sehingga usaha tersebut tetap berjalan dengan baik. Penelitian ini mendukung penelitian Sarwana dan Indra (2011) terbukti bahwa informasi pasar berpengaruh positif terhadap penerapan CRM.

\section{Pengaruh Human Capital terhadap Kapabilitas CRM}

Hasil penelitian menunjukkan bahwa human capital mempunyai pengaruh positif dan signifikan terhadap kapabilitas CRM, memberikan pengertian bahwa semakin meningkat human capital maka perusahaan dapat memanfaatkan dan mengembangkan pengetahuan, kompetensi dan keterampilan secara efisien, sehingga akan berdampak pada meningkatnya kapabilitas pengetahuan pemilik/pengusaha tentang keinginan pelanggan, dinamika pasar dan pesaingsemakin meningkat human capital maka perusahaan dapat memanfaatkan dan mengembangkan pengetahuan, kompetensi dan keterampilan secara efisien, sehingga akan berdampak pada meningkatnya kapabilitas pengetahuan pemilik/pengusaha tentang keinginan pelanggan, dinamika pasar dan pesaing.

Hubungan yang baik tentu akan membuat konsumen percaya dan hal itulah yang perlu dijadikan prioritas utama dalam memberikan layanan kepada para pelanggan. Penelitian ini mendukung Christa (2013) menunjukkan 
bahwa human capital mempunyai pengaruh positif terhadap kapabilitas CRM dan kinerja organisasi. Akan tetapi penelitian ini tidak mendukung penelitian Juwita (2007) terjadi sebaliknya bahwa human capital tidak berpengaruh terhadap kapabilitas CRM dan kinerja bisnis.

\section{Pengaruh Informasi Pasar terhadap Kinerja Pemasaran}

Hasil penelitian menunjukkan bahwa informasi pasar mempunyai pengaruh positif dan signifikan terhadap kinerja pemasaran, dapat diartikan bahwa semakin tinggi informasi pasar yang diterima, maka pemilik/pengusaha tersebut akan merespon dengan baik terhadap perubahanperubahan yang terjadi pada perusahaan, sehingga mampu meningkatkan kinerja pemasaran perusahaan. Hal ini sesuai pernyataan Rolfe (1922) bahwa semakin tinggi informasi pasar yang diterima, maka akan semakin meningkatkan persaingan pasar, sehingga perusahaan akan meningkatkan jarak produk dan mengurangi siklus hidup produk, memperkenalkan saluran distribusi baru yang mempengaruhi rantai suplai konsumen, menghadapi sensitivitas pasar dan menargetkan produk serta jasa kepada segmen-segmen pelanggan. Semakin banyak informasi pasar yang diterima, maka para pemilik/ pengusaha tepung akan merespon dengan baik terkait dengan perubahan yang terjadi di lingkungan perusahaan, terutama terkait dengan strategi penjualan yang diterapkan perusahaan dalam meraih pangsa pasar, yaitu dengan memanfaatkan media internet yang memudahkan orang untuk mengakses.

Dengan memanfaatkan informasi pasar, maka akan lebih mudah dalam mengetahui permintaan pasar per bulan atau per tahunnya, sehingga tingkat proses produksi yang dilakukan perusahaan akan jelas dan tentu akan mempengaruhi tingginya kinerja para pemasar dalam memasarkan produknya. Hal ini mendukung dengan penelitian yang dilakukan oleh Wright dan
Ashill (1998) menunjukkan bahwa informasi pasar berpengaruh positif terhadap kinerja perusahaan.

\section{Pengaruh Human Capital terhadap Kinerja Pemasaran}

Hasil penelitian menunjukkan human capital mempunyai pengaruh positif dan signifikan terhadap kinerja pemasaran, dapat diartikan bahwasemakin meningkat human capital maka perusahaan dapat memanfaatkan dan mengembangkan pengetahuan, kompetensi dan keterampilan karyawannya secara efisien, sehingga akan berdampak pada meningkatnya kinerja pemasaran perusahaan. Human capital memiliki peran sangat urgen sebagai komponen kunci yang mempengaruhi tinggi-rendahnya tingkat kinerja sebuah organisasi/perusahaan (Sangkala., 2006).

Kepedulian yang tinggi terhadap apa yang diingikan konsumen juga sangat diperlukan oleh pihak manajemen perusahaan. Untuk itu pihak manajemen harus berusaha sekuat mungkin untuk mampu dalam memajukan perusahaan agar tetap bertahan dan berkembang, salah satunya dengan membangun kepercayaan menjadi prioritas utama dalam memberikan pelayanan kepada para pelanggannya.

Hasil penelitian ini mendukung penelitian Saeed, dkk (2013), Ramanda dan Mochtar (2014) telah membuktikan bahwa human capital mempunyai pengaruh positif terhadap kinerja organisasi. Pada penelitian Christa (2013) dan Mehralian, et.al (2012) menunjukkan bahwa human capital mempunyai pengaruh positif terhadap kinerja organisasi. Akan tetapi penelitian ini tidak didukung oleh penelitian yang dilakukan Juwita (2007) bahwa human capital tidak berpengaruh terhadap kinerja bisnis.

\section{Pengaruh Kapabilitas CRM terhadap Kinerja Pemasaran}

Hasil penelitian menunjukkan bahwa kapabilitas CRM mempunyai 
pengaruh positif signifikan terhadap kinerja pemasaran. Hasil pengujian tersebut dapat diartikan bahwa semakin tinggi pengetahuan pemilik/pengusaha dalam memahami keinginan pelanggan, dinamika pasar dan pesaing, maka akan semakin meningkatkan kinerja pemasaran perusahaan. Hal ini sesuai pernyataan Sin et al. (2005) menjelaskan bahwa kapabilitas CRM merupakan strategi yang diperlukan perusahaan untuk mengoptimalkan keuntungan dalam meningkatkan kinerja yang dihasilkan. Pentingnya implementasi CRM pada perusahaan juga disebabkan kapabilitas CRM memiliki kemampuan untuk memahami apa yang menjadi kebutuhan pelanggan serta mengantisipasi perilaku negatif pada saat berinteraksi langsung dengan pelanggan. Pihak manajemen harus melakukan evaluasi dengan menciptakan hubungan jangka panjang guna mengukur seberapa besar tingkat kepuasan para pelanggan. Bentuk hubungan tersebut bisa dilihat dari strategi yang diterapkan pihak manajemen perusahaan melalui kesesuaian penerapan penjualan produk dengan harga pasar.

Penelitian ini mendukung dengan penelitian yang dilakukan Chang (2007), Fazlzadeh, et.al (2011), Nguyen, et.al (2007), Coltman, et.al (2011) serta Wang dan Feng (2012) yang menyatakan bahwa kapabilitas CRM berpengaruh positif dan signifikan terhadap kinerja bisnis.

\section{Pengaruh Langsung dan Tidak Langsung}

Hasil penelitian terbukti bahwa kapabilitas CRM tidak mampu menjadi variabel intervening antara informasi pasar dengan kinerja pemasaran. Dengan demikian informasi pasar hanya berpengaruh terhadap kinerja pemasaran tetapi tidak melalui kapabilitas CRM..Hal ini memberikan pengertian bahwa semakin tinggi informasi pasar yang diterima, maka pemilik/pengusaha tersebut akan merespon dengan baik terhadap perubahan-perubahan yang terjadi dalam meningkatkan kinerja pemasaran perusahaan, akan tetapi tidak mampu meningkatkan kapabilitas CRM. Hal tersebut karena keterbatasan pendidikan yang dimiliki pemilik/pengusaha, sehingga informasi pasar yang diperoleh tidak mampu dimanfaatkan dengan baik dalam melakukan perubahan yang terjadi pada perusahaan dalam meningkatkan kinerja pemasarannya. Hasil penelitian juga menunjukkan bahwa kapabilitas CRM tidak mampu menjadi variabel intervening antara human capital dengan kinerja pemasaran. Dengan demikian human capital hanya berpengaruh terhadap kinerja pemasaran tetapi tidak melalui kapabilitas CRM. Dengan demikian semakin meningkat human capital maka perusahaan hanya dapat memanfaatkan dan mengembangkan pengetahuan, kompetensi dan keterampilan karyawannya secara efisien dalam upaya meningkatkan kinerja pemasaran perusahaan, tetapi tidak melalui kapabilitas CRM. Hal tersebut disebabkan karena tidak diimbangi dengan kempuan pemilik/pengusaha dalam memanfaatkan dan mengembangkan pengetahuan, kompetensi dan keterampilan secara efisien, sehingga kapabilitas pengetahuan pemilik/pengusaha terbatas, terkait dengan keinginan pelanggan, dinamika pasar dan pesaing dalam meningkatkan kinerja pemasaran.

\section{SIMPULAN}

Berdasarkan penelitian yang telah dilakukan maka dapat diperoleh kesimpulan sebagai berikut :

Informasi pasar terbukti mempunyai pengaruh positif dan signifikan terhadap kapabilitas CRM, dapat diartikan bahwa semakin tinggi informasi pasar yang diterima, maka pemilik/pengusaha tersebut akan merespon dengan baik terhadap perubahanperubahan yang terjadi pada perusahaan, sehingga mampu meningkatkan kapabilitas pengetahuan tentang keinginan pelanggan, dinamika pasar dan pesaing.

Human capital mempunyai pengaruh 
positif dan signifikan terhadap kapabilitas CRM, artinya semakin meningkat human capital maka perusahaan dapat memanfaatkan dan mengembangkan pengetahuan, kompetensi dan keterampilan secara efisien, sehingga akan berdampak pada meningkatnya kapabilitas pengetahuan pemilik/pengusaha tentang keinginan pelanggan, dinamika pasar dan pesaing.

Informasi pasar terbukti mempunyai pengaruh positif dan signifikan terhadap kinerja pemasaran, maka pemilik/ pengusaha tersebut akan merespon dengan baik terhadap perubahan-perubahan yang terjadi pada perusahaan, sehingga mampu meningkatkan kinerja pemasaran perusahaan.

Human capital mempunyai pengaruh positif dan signifikan terhadap kinerja pemasaran, dapat diartikan bahwa semakin meningkat human capital maka perusahaan dapat memanfaatkan dan mengembangkan pengetahuan, kompetensi dan keterampilan karyawannya secara efisien, sehingga akan berdampak pada meningkatnya kinerja pemasaran perusahaan.

Kapabilitas CRM mempunyai pengaruh positif signifikan terhadap kinerja pemasaran. Hasil pengujian tersebut dapat diartikan bahwa semakin tinggi pengetahuan pemilik/ pengusaha dalam memahami keinginan pelanggan, dinamika pasar dan pesaing, maka akan semakin meningkatkan kinerja pemasaran perusahaan.

Kapabilitas CRM tidak mampu menjadi variabel intervening antara informasi pasar dan human capital dengan kinerja pemasaran. Dengan demikian informasi pasar dan human capital hanya berpengaruh terhadap kinerja pemasaran perusahaan tetapi tidak melalui kapabilitas CRM.

Untuk meningkatkan kinerja pemasaran, maka hendaknya ada beberapa hal yang perlu dilakukan evaluasi bagi pihak tenaga pemasaran, diantaranya:

Hendaknya informasi harga pesaing tidak selamanya diterima, akan tetapi dapat digunakan sebagai pembanding karena tidak selamanya harga yang murah sebagai pedoman. Penetapan harga disesuaikan dengan penetapan biaya bahan baku, tenaga kerja dan overhead pabrik dengan tetap mengedepankan kualitas produk, maka harga yang tidak terlalu mahal akan menjadi daya tarik konsumen untuk membeli.

Hendaknya pihak manajemen perlu mengkaji dengan melihat informasi yang dilakukan pesaing terutama dalam memberikan pelayanan kepada para pelanggan tanpa adanya keluhan terkait pengiriman barang.

Dalam upaya meningkatkan human capital, maka terdapat beberapa hal yang perlu mendapatkan perhatian dari pihak manajemen kolam pemancingan, antara lain:

Perlu adanya kepedulian yang tinggi terhadap apa yang diinginkan konsumen, yaitu dengan menindaklanjuti terhadap apa yang dikeluhkan konsumen, seperti komplain terhadap kualitas produk, keterlambatan pengiriman dan lain-lain.

Hendaknya pihak manajemen tetap memprioritas kepercayaan sebagai faktor yang harus dikedepankan, agar terjalin hubungan dengan pelanggan dalam jangka yang panjang.

Hendaknya pihak manajemen perlu melakukan evaluasi untuk memahami keinginan pelanggan, dinamika paasar dan pesaing yaitu dengan menyesuaikan penjualan suatu produk dengan harga pasar sehingga dapat meningkatkan kinerja pemasaran.

Untuk meningkatkan kinerja pemasaran perusahaan yang optimal, maka pihak pemilik atau pengusaha tepung tapioka di Kabupaten Pati perlu mengetahui informasi pasar dengan baik yaitu dengan memanfaatkan teknologi informasi dengan didukung peran human capital dalam penciptaan kekayaan intelektual sehingga pengetahuan yang dimiliki akan lebih memadai terutama dalam mengembangkan produk baru berdasarkan pengetahuan yang lengkap tentang keinginan pelanggan, 
dinamika pasar dan pesaing pengelola perusahaan

Teknik pengumpulan data yang dipakai dalam penelitian ini hanya menggunakan kuesioner sehingga kesimpulan yang dapat diambil hanya berdasarkan pada data yang dikumpulkan melalui kuesioner tersebut. Data yang dianalisis merupakan persepsi jawaban responden yang dapat menimbulkan masalah jika jawaban responden tidak sesuai dengan keadaan yang sesungguhnya, sehingga pada penelitian selanjutnya ditambah dengan teknik wawancara sehingga akan lebih memperkuat keakuratan data.

Sampel penelitian ini hanya sebesar 62 responden, sehingga apabila diterapkan dengan sobel test yang membutuhkan jumlah sampel yang besar (sesuai ketentuan Ghozali, 2011) maka pengujian ini tidak mampu memenuhi kelayakan variabel intervening, sehingga diperlukan untuk memperluas obyek penelitian.

Penelitian ini hanya terbatas pada pemilik/pengusaha tepung tapioka di Kabupaten Pati, sehingga memperoleh jumlah sampel yang kecil karena kesibukan pemilik/pengusaha. Untuk itu pada penelitian selanjutnya perlu memperluas obyek penelitian yaitu para pemilik/pengusaha di Jawa untuk memperluas jumlah sampel yang banyak sehingga dapat menunjukkan ke akuratan hasil penelitian.

\section{DAFTAR PUSTAKA}

Bontis, N., Keovv, W.C.C. and Richardson, S. (2002). Intellectual Capital and Business Performance in Malaysian Industries. Journal o f Intellectual Capital, 1 (1)

Chadhiq., Umar. (2007). Customer Relationsip Management (CRM) : Pilihan strategi untuk meraih keunggulan bersaing. Jurnal Management Bisnis.

Daft, R. (2009). Organization Theory and Design, 10th ed., South-Western College Publishing, Cincinnati, $\mathrm{OH}$

Ferdinand, A. (2009). Metode Penelitian Manajemen. Semarang: BP.UNDIP

Ghozali, I. (2011). Aplikasi Analisis Multivariate Dengan Program SPSS. Semarang: Badan Penerbit Universitas Diponegoro.

Juwita, S. P. (2007). Pengaruh human capital terhadap business performance melaui customer capital. Jurnal Akuntansi dan Keuangan Indonesia, 4 (2).

Mangkunegara, A.A., Anwar, P. (2012). Manajemen Sumber Daya Manusia. Jakarta: Rineka Cipta,

Margaretha., Farah., dan Arief, R. (2006). Analisis Pengaruh Intellectual Capital terhadap Market Value dan Financial Performance Perusahaan dengan Metode Value Added Intellectual Coefficient. Jurnal Bisnis dan Akuntansi, 8 (2) : 199-217.

Maun., Ariyani, M. (2012). Hubungan Organizaton Learning, informasi pasar, inovasi dan kinerja pasar. Jurnal Sains Pemasaran Indonesia, I (2).

Sangkala. (2006). Management Knowledge. Jakarta: PT. Raya Grafindo Persada.

Simamora, Henry 2009, Manajemen Sumber Daya Manusia. Yogyakarta: STIE YKPN.

Sin, Leo Y.M., Alan Tse C.B. Yim, Frederick H.K. (2005). CRM: Conceptualization and Scale Development. European Journal of Marketing, 39 (11/12) : 1264-1290.

Sugiyono. (2011). Metodologi Penelitian. Jakarta: Alfa Beta.

Umar, H. (2008). Metodologi Penelitian : Aplikasi dalam Pemasaran. Jakarta: PT. Gramedia Pustaka Utama.

Wang, Yonggui dan Hui Feng. (2012). Customer Relationship Mangement Capabilities : measurement, antecedents and consequences. Management Decision, 50 (1). 